\title{
KRIMINALITETSUTVIKLINGEN I NORGE SIDEN 1980
}

Av PROFESSOR RAGNAR HAUGE

Norway began recording criminal statistics in 1835. Between 1835 and 1950, registered crime was characterised by cycles of increase and decrease, each lasting about 10 to 15 years. Since 1955, however, Norway has witnessed a steady increase in registered crime from one year to the next, which is documented in the current paper. This increase seems to have been unaffected by large scale social changes occurring during the move from modernity to late modernity, or by the shift from a humanitarian, rehabilitative crime control perspective to the recent policy of "zero tolerance"."

Til det 9. nordiske kriminalistmøtet i 1984 utarbeidet Sturla Falch en rapport om kriminalitetsutviklingen i Norge fra 1950 til 1980 (NTfK 1984:126-148). Ett av hans poenger var at når man så på kriminalitetsutviklingen i de nær 150 år fra 1835 og frem til 1980 - den periode hvor man har offisielle kriminalstatistiske data - fortonet utviklingen seg som en bølgegang. Oppgangstider som strakte seg over 10-15 år, ble avløst av nedgangstider av omtrent samme lengde. Men fra midten av 1950-årene og frem til 1980 fant man imidlertid en ubrutt oppgang uten tegn til at oppgangsbølgen var i ferd med å gå ned.

Nå - vel 20 år senere - kan vi fastslå at den oppgangsbølgen i den registrerte kriminaliteten som startet rundt midten av 1950-årene, har fortsatt med uforminsket styrke helt frem til i dag, slik det fremgår av tabell 1. I tabellen har vi for oversiktlighetens skyld valgt å angi tall for hvert femte år i perioden 1960-2000 i og med at endringene fra det ene år til det neste ikke avviker særlig mye. Vi har dessuten tatt med de upubliserte data for 2001 som foreligger.

Som det fremgår av tabellen har antallet etterforskede forbrytelser steget fra nær 39000 til vel 310000 fra 1960 til 2001, noe som innebærer noe nær en åttedobling. Når det gjelder antallet siktede for forbrytelser - som omfatter personer som politiet mener er skyldige i lovbrudd, derunder også dem under den kriminelle lavalder, men hvor samme person kan pådra seg flere siktelser i løpet av samme år - har dette steget fra vel 9000 i 1960 til nær 38000 i 2001, som er mer enn en firedobling. Hva endelig gjelder antallet straffereaksjoner for forbrytelser - som angir antall personer som er blitt ilagt en strafferettslig sanksjon, men også her hvor en og samme person kan telles flere ganger dersom vedkommende ved to eller flere tilfelle har blitt straffelt i løpet av året - har dette $\emptyset \mathrm{kt}$ fra

\footnotetext{
* Title in English: Trends in Norwegian Crime Since 1980. Original in Norwegian.
} 
nær 6000 i 1960 til nær 35000 i 2001, som er nær en seksdobling. Økningen fra 2000 til 2001 er imidlertid så påfallende at det synes å være grunn til å stille seg litt skeptisk til tallet.

Tabell 1: Utviklingen $i$ antall etterforskede forbrytelser, siktede og straffereaksjoner for forbrytelser i Norge hvert femte år i perioden 1960-2000 og 2001.

\begin{tabular}{|c|c|c|c|}
\hline & $\begin{array}{l}\text { Etterforskede for- } \\
\text { brytelser }\end{array}$ & $\begin{array}{l}\text { Siktede for for- } \\
\text { brytelser }\end{array}$ & $\begin{array}{l}\text { Straffereaksjoner } \\
\text { for forbrytelser }\end{array}$ \\
\hline 1960 & 38.700 & 9178 & 5708 \\
\hline 1965 & 47.654 & 9524 & 7112 \\
\hline 1970 & 65.080 & 1947 & 9347 \\
\hline 1975 & 98.471 & 12.466 & 9677 \\
\hline 1980 & 121.565 & 13.585 & 10.595 \\
\hline 1985 & 164.067 & 15.986 & 12.959 \\
\hline 1990 & 235.256 & 22.873 & 15.729 \\
\hline 1995 & 269.282 & 25.112 & 17.754 \\
\hline 2000 & 314.027 & 34.235 & 21.444 \\
\hline 2001 & 310.447 & 37.995 & 34.962 \\
\hline
\end{tabular}

Økningen i den registrerte kriminaliteten varierer imidlertid sterkt alt etter hvilke forbrytelser det er tale om. For å belyse dette har vi i tabell 2 og 3 valgt ut noen forbrytelseskategorier og sett disse i relasjon til antall etterforskede forbrytelser og antall straffereaksjoner for forbrytelser per femte år i perioden 1980-2000, foruten i 2001.

Tabell 2: Antall etterforskede forbrytelser og prosentandel av samtlige etterforskede forbrytelser innenfor ulike forbrytelsestyper i Norge hvert femte år i perioden 1980-2000 og 2001.

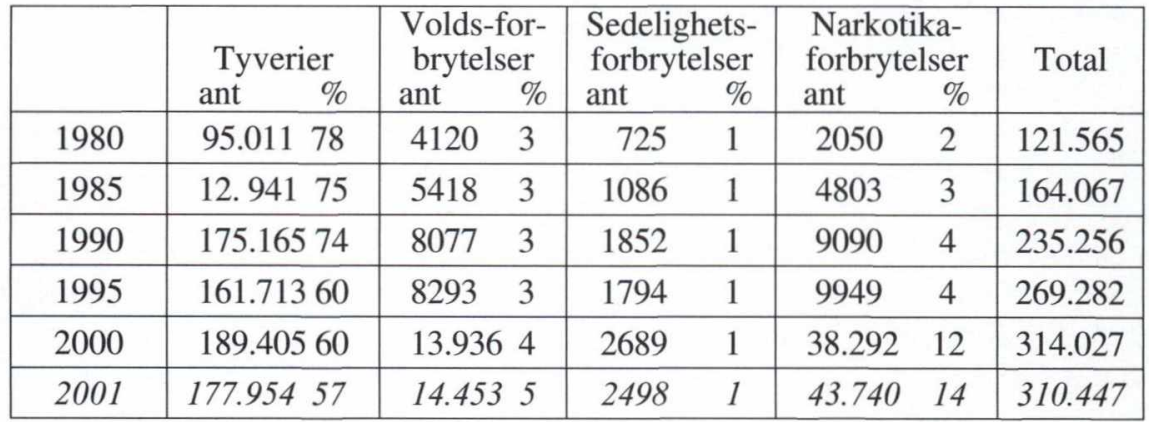


Som det fremgår av tabell 2 er antallet etterforskede tyverier i 2001 nær det dobbelte i forhold til 1980, mens etterforskede voldsforbrytelser og sedelighetsforbrytelser er mer enn tre ganger så høyt som i 1980. Sedelighetsforbrytelsene er imidlertid tallmessig få. For samtlige forbrytelser har det vært en $\emptyset \mathrm{kning}$ fra det ene femår til det neste, men med et par unntak. Fra 1990 til 1995 gikk tyvsforbrytelsene ned, før de pånytt steg og nådde et nytt høydepunkt i 2000 for igjen å synke noe i 2001. Den forbrytelsestypen som uten sammenlikning har $\emptyset \mathrm{kt}$ mest er imidlertid narkotikaforbrytelsene hvor antallet etterforskede forbrytelser er nær 21 ganger så mange som i 1980. Særlig sterk er økningen fra 1995 til 2000 hvor antallet $\varnothing$ kte fra nær 10000 til over 38 000, og videre til nær 44000 i 2001. Til dels kan denne $\varnothing$ kningen tilbakeføres til en endring i tellemåten etter 1995, ved at hvert enkelt lovbrudd - selv om det knytter seg til samme forhold - telles med. Når det gjelder narkotika skal f eks kjøp, besittelse og bruk - som ofte vil stå i nær sammenheng med hverandre - telles som tre ulike forbrytelser. Men dette er ikke hele forklaringen på $\varnothing$ kningen.

Tabell 3: Antall straffereaksjoner for ulike forbrytelseskategorier $i$ Norge hvert femte år $i$ perioden 1980-2000 og 2001.

\begin{tabular}{|c|c|c|c|c|c|}
\hline & Tyverier & $\begin{array}{c}\text { Volds-for- } \\
\text { brytelser }\end{array}$ & $\begin{array}{c}\text { Sedelighets- } \\
\text { forbrytelser }\end{array}$ & $\begin{array}{c}\text { Narkotika- } \\
\text { forbrytelser }\end{array}$ & Total \\
\hline 1980 & 6004 & 782 & 217 & 687 & 10.595 \\
\hline 1985 & 6159 & 1046 & 242 & 1872 & 12.959 \\
\hline 1990 & 5682 & 1762 & 426 & 3098 & 15.729 \\
\hline 1995 & 4537 & 2391 & 344 & 4097 & 17.754 \\
\hline 2000 & 4251 & 2420 & 356 & 8344 & 21.444 \\
\hline 2001 & 5887 & 3794 & 510 & 14.770 & 34.962 \\
\hline
\end{tabular}

At $\varnothing$ kningen i narkotikaforbrytelser ikke bare kan tilbakeføres til endringer i tellemåten, fremgår av tabell 3, som viser at også antallet straffereaksjoner for narkotikaforbrytelser har $\varnothing \mathrm{kt}$ sterkt gjennom hele perioden. Og her er det personen, og ikke lovbruddet, som er telleenheten. Særlig sterk er økningen fra 1995 til 2000 hvor tallet ble mer enn fordoblet, og fra 2000 til 2001 hvor $\varnothing$ kningen var vel 50 prosent. Også når det gjelder voldsforbrytelser og sedelighetsforbrytelser har det vært en klar $\varnothing \mathrm{kning}$ i antallet straffereaksjoner gjennom hele perioden også her med en påfallende økning fra 2000 til 2001 - selv om økningen har vært markant lavere enn for narkotikaforbrytelser. Antall straffereaksjoner for tyverier viser derimot en klar nedgang fra 1980 til 2000, til tross for at antallet etterforskede tyvsforbrytelser med et par unntak viste en klar stigning. I 2001 var det derimot en ny $ø$ kning, slik at antallet nærmet seg antallet i 1980. Forklaringen på 
nedgangen ligger trolig i en lavere oppklaringsfrekvens og kanskje også i at den enkelte straffelte gjennomgående straffes for flere tyverier enn tidligere.

At antallet straffereaksjoner for tyverier i 2002 ligger nær en tredjedel lavere enn i 1980 - mens voldsforbrytelser og narkotikaforbrytelser viser en klar $\varnothing$ kning - innebærer en markant endring i sammensetningen av de straffelte. Mens andelen straffereaksjoner for tyverier i 1980 utgjorde 57 prosent av samtlige straffereaksjoner, var den i 2001 sunket til 17 prosent. Omvendt har andelen straffelte for voldsforbrytelser $\emptyset \mathrm{kt}$ fra 7 til 11 prosent. Mest markert har $\emptyset \mathrm{kningen} \mathrm{vært} \mathrm{når}$ det gjelder straffelte for narkotikaforbrytelser: De utgjorde i 19806 prosent av samtlige, mens andelen i 2002 var steget til 42 prosent.

Siden 1980 har det også skjedd andre endringer i kriminalitetsbildet, nemlig når det gjelder kjønns- og alderssammensetningen, slik det fremgår av tabell 4. I tabellen har vi valgt å ta for oss siktede for forbrytelser - fordi denne også omfatter barn og ungdom under den kriminelle lavalder. Som det fremgår av tabellen har antall siktede kvinner $\varnothing \mathrm{kt}$ fra 8,9 prosent i 1980 til 15,6 prosent i 2000 . Like påfallende er endringen når det gjelder alderssammensetningen. Mens aldersgruppen 24 år og under i 1980 utgjorde vel 70 prosent av alle siktede, var andelen i 2000 sunket til 49 prosent - og særlig markert var nedgangen blant de aller yngste.

Tabell 4: Antall siktede for forbrytelser i 1980 og 2000 fordelt på kjønn og alder.

\begin{tabular}{|l|c|c|c|c|}
\hline & \multicolumn{2}{|c|}{1980} & \multicolumn{2}{c|}{2000} \\
\hline & Antall & Prosent & Antall & Prosent \\
\hline Kjønn: & & & & \\
\hline Kvinner & 1.209 & 9 & 5.341 & 16 \\
\hline Menn & 12.376 & 91 & 28.894 & 84 \\
\hline Total & 13.585 & 100 & 34.235 & 100 \\
\hline Alder: & & & & \\
\hline Inntil 17 år & 4.707 & 35 & 6.671 & 20 \\
\hline 18-24 år & 4.909 & 36 & 10.079 & 29 \\
\hline Over 24 år & 3.969 & 29 & 17.469 & 51 \\
\hline Total & 13.585 & 100 & 34.219 & 100 \\
\hline
\end{tabular}

Begge disse utviklingstrekkene er nye i bildet. Kvinnenes andel av siktede for forbrytelser lå fra 1960-årene og helt frem til slutten av 1980-årene på mellom 8 og 10 prosent. I 1990-årene begynte imidlertid andelen å $\varnothing \mathrm{ke}$ fra år til annet inntil det i 2000 nådde nær 16 prosent. Når det gjelder aldersfordelingen skyldtes $\emptyset$ kningen i det totale antall siktede fra midten av 1950-årene og frem til 1980årene nesten utelukkende en økning blant de unge. I det første tiåret var det særlig de aller yngste som dominerte - fra politistatistikken ble etablert i 1957 og 
utover i 1960-årene var det 14-17-åringene som hadde den høyeste frekvensen siktede tett fulgt av 10-13-åringene, og aldersgruppen inntil 17 år utgjorde mer enn halvparten av samtlige siktede for forbrytelser. Etter 1970 sank frekvensen blant de aller yngste sterkt, mens 14-17-åringene fortsatte å $\varnothing \mathrm{ke}$. Økningen innenfor aldersgruppen 18-20 år var imidlertid fra begynnelsen av 1970-årene enda sterkere, og i 1979 overtok denne aldersgruppen ledelsen med den høyeste frekvensen av siktede. Samtidig fikk man utover på 1980-tallet en sterk økning også blant de noe eldre aldersgruppene, slik at aldersgruppen over 24 år, som i 1960 bare utgjorde 32 prosent av samtlige siktede for forbrytelser - i kraft av at de er så mange tallmessig - i 2000 utgjorde over halvparten, mens andelen blant dem inntil 18 år var sunket fra over halvparten i 1960 til mindre enn en femtedel i 2000.

Kriminalstatistikken var tidligere i hovedsak begrenset til å gjelde forbrytelser - som i all hovedsak omfatter det man kan betegne som tradisjonelle lovbrudd som omhandles i straffeloven. Forseelsene ble det inntil nylig bare gitt enkelte summariske opplysninger om. Dette innebar at man manglet opplysninger om de nye former for lovbrudd, som lovbrudd mot skatte- og avgiftslovgivningen, miljøkriminalitet og liknende - som i hovedsak var straffbare etter særlovgivningen og oftest rubrisert som forseelser. Etter hvert har imidlertid stadig flere av de mer alvorligere former for slik kriminalitet blitt omgjort til forbrytelser. Samtidig har det skjedd omlegginger av kriminalstatistikken i forbindelse med at datateknologien er tatt i bruk ved innsamling av opplysninger fra politi og påtalemyndighet, slik at statistikken kan gi mer detaljerte opplysninger også om forseelseskriminaliteten.

Til tross for at slike moderne lovbrudd ofte oppleves som alvorligere enn mange tradisjonelle lovbrudd, er de i liten grad gjenstand for straffeforfølgelse. De lovene som oftest fører til en straffesak er lov om merverdiavgift, ligningsloven og arbeidsmiljøloven - selv om bestemmelsene om bedrageri, underslag, dokumentfalsk mv i enkelte tilfelle vil kunne komme til anvendelse. Ut fra det man vet om utbredelsen av svart arbeid, skattesvik og arbeidsforhold på enkelte typer av arbeidsplasser er det grunn til å tro at antallet overtredelser av disse lovene er svært høyt. Men tallmessig er det et ikke mange slike saker som fører til strafferettslige sanksjoner. I 2000 ble det etterforsket 991 lovbrudd mot lov om merverdiavgift, 1844 mot ligningsloven og 560 mot arbeidsmiljøloven, og til sammen var det 854 personer som ble straffesanksjonert for overtredelser av disse lovene. Dette kan utvilsomt skyldes mange forhold. De er ofte kompliserte å etterforske og bevisførselen for retten er ofte vanskelig. Dessuten åpner lovgivningen i mange tilfelle adgang til å anvende sivilrettslige sanksjoner som $\mathrm{f}$ eks straffeskatt eller inndragning av bevillinger, som er vesentlig enklere å anvende. 
Kriminalstatistikken er velegnet når det gjelder å beskrive utviklingen av den registrerte kriminalitet - den kriminaliteten som kommer til myndighetenes kjennskap. Men i hvilken grad den registrerte kriminaliteten er representativ for den faktiske kriminaliteten er et åpent spørsmål? Fordi økningen i den registrerte kriminaliteten har vært så stor og konsistent er det god grunn til å tro at også den faktiske kriminalitet har $ø$ kt. Men samtidig kan man ikke utelukke at en vesentlig del av $\varnothing$ kningen kan tilbakeføres til endringer i kontrollsystemet. Dette innebærer at forklaringer på de endringer - eller mangel på endringer - som man kan påvise på grunnlag av kriminalstatistikken, på den ene siden kan ta utgangspunkt i forhold som kan ha påvirket folks tilbøyelighet til å begå straffbare handlinger, og på den annen side til forhold ved kontrollsystemet som har ført til at flere straffbare handlinger anmeldes, oppklares og tilretteføres.

Man kan peke på mange forhold som taler for at lovbrudd har blitt mer utbredt enn tidligere. Samfunnsforholdene i Norge - i likhet med det som har skjedd i svært mange andre land - har undergått store endringer i løpet av de siste tiår, og særlig markert fra slutten av 1970-tallet. Stikkord som endrede familiestrukturer og kjønnsroller, et flerkulturelt samfunn, nedbygging av velferdsstaten, $\varnothing$ kende $\varnothing$ konomiske forskjeller - eller for å bruke enda mer svepende generaliseringer som globalisering og markeds $\varnothing$ konomi, som er kjennetegn ved det som ofte betegnes som det senmoderne samfunn - er forhold som har vært pekt på som årsaker til økt kriminalitet. Det hevdes at utviklingen har ført til at den informelle sosiale kontroll - fra familien, nabolaget, arbeidskollektivet og andre grupper - som tidligere styrte individene, mer eller mindre er gått i oppløsning. Den livslange familie er avløst av singelliv, seriemonogami og eneforeldre, nabolagstilhørigheten svekket som følge av flyttinger, samlivsbrudd og endrede fritidsvaner og tilknytningen til arbeidskolleger redusert som følge av ustabile arbeidsplasser. Verdigrunnlaget er endret ved at konsum og materielle goder er blitt de sentrale verdier på bekostning av verdier som moral, likhet og solidaritet, og man har fătt en ny underklasse av innvandrere hvis barn brytes mellom foreldrenes og det omgivende samfunns normer.

Kanskje kan dette forklare ikke bare den $\emptyset$ kte kriminaliteten, men også andre endringer i kriminalitetsbildet. Utvidelsen av ungdomstiden - en periode av livet da man er under utdannelse og uten å ha dannet familie - kan kanskje forklare at tradisjonell kriminalitet, som på mange kan sees som karakteristisk for ungdomsperioden, etter hvert har blitt mer utbredt også i de noe eldre aldersgruppene. Og den økte kvinneandelen kan kanskje sees som et uttrykk for at forskjellene mellom kjønnene er blitt mindre.

Samtidig har det vært en utvikling i retning av et hardere kriminalpolitisk klima preget av en styrking av politiet og innføring av nye etterforskningsmetoder på den ene siden og nykriminalisering og strengere straffer på den annen. Dette har vært forsøkt forklart med på den ene siden økningen i den registrerte kriminalitet, at lovbruddene stadig blir grovere og ikke minst de nye former for kriminalitet man 
har vært vitne til i de senere år som profesjonell narkotikakriminalitet, gatevold, oppblomstring av nynazisme, et kriminelt mc-miljø og gjengdannelser blant innvandrerungdom. En annen type av forklaringer knytter seg til at beskrivelsene av kriminalitet $\mathrm{i}$ aviser og fjernsyn etter hvert har $\varnothing \mathrm{kt} \mathrm{i}$ omfang og blitt mer dramatiske og detaljerte, og at dette, koplet med at folk er blitt fremmede og utrygge overfor hverandre, har ført til at befolkningens opptatthet av og engstelse for kriminalitet $\varnothing \mathrm{kt}$. Begge forhold har ført til at kravet om strengere tiltak mot de kriminelle har fătt gjennomslag. I Norge har dette blant annet gitt seg utslag i at antallet årsverk innenfor politi- og lensmannsetaten har økt fra 6665 i 1980 til 11 134 i 2000 - med to tredjedeler - og at straffene for en rekke lovbrudd er hevet, til dels betraktelig. Det aller siste er at vi har fått en generell bestemmelse om heving av straffen ved gjengangerkriminalitet og forslag fra justisdepartementet om heving av den øvre strafferamme fra 21 til 30 års fengsel.

Det strengere kriminalpolitiske klimaet synes også å bli bekreftet i straffeutmålingen, slik det fremgår av tabell 5 , hvor vi for enkelte forbrytelseskategorier har angitt hvor stor andel som er gitt ubetingede fengselsstraffer i henholdsvis 1980, 1990 og 2000. For en del kategorier er det riktignok tale om små tall, slik at tilfeldigheter kan ha gitt seg utslag. Når det gjelder de tallmessig store kategoriene som simple og grove tyverier og $\emptyset$ vrige vinningsforbrytelser er det en relativt klar tendens i retning av at fengselsstraff i stadig større grad har kommet til anvendelse, og det samme gjelder for sedelighetsforbrytelser. Utviklingen når det gjelder voldsforbrytelser er mer uklar - når det gjelder legemsfornærmelsene viser disse en nedgang i bruken av ubetinget fengselsstraff, mens forholdet er omvendt når det gjelder legemsbeskadigelser. Trusler og tvang og ran har ligget på omtrent samme nivå i de tre årene. Bruken av ubetinget fengsel overfor narkotikaforbrytelser synes å vise en dramatisk nedgang fra 1980 til 1990. Dette skyldes imidlertid en lovendring som overførte enkelte mer alvorlige lovbrudd, som tidligere ble rammet av legemiddelloven, til straffeloven. Dette innebar at bare de minst alvorlige lovbrudd ble tilbake i legemiddelloven, mens straffeloven ble utvidet til også å ramme en del mindre alvorlige narkotikalovbrudd. Men utviklingen fra 1990 til 2000 tyder på at det for narkotikalovbrudd har vært en viss reduksjon i straffenivået, i motsetning til det som-gjelder andre typer av lovbrudd. 
Tabell 5: Prosent ubetingede fengselsstraffer for ulike typer av forbrytelser 1980, 1990 og 2000.

\begin{tabular}{|l|c|c|c|}
\hline & 1980 & 1990 & 2000 \\
\hline Simpelt tyveri & 17,3 & 18,7 & 28,1 \\
\hline Grovt tyveri & 44,7 & 48,6 & 58,0 \\
\hline Simpelt bedrageri & 27,6 & 26,1 & 36,5 \\
\hline Grovt bedrageri & 68,6 & 64,0 & 61,0 \\
\hline Simpelt underslag & 14,1 & 15,5 & 43,5 \\
\hline Grovt underslag & 64,6 & 58,0 & 63,0 \\
\hline Legemsfornærmelse & 22,7 & 21,6 & 14,3 \\
\hline Legemsbeskadigelse & 65,4 & 77,2 & 84,8 \\
\hline Trusler og tvang & 52,6 & 56,0 & 56,2 \\
\hline Ran & 81,1 & 85,5 & 75,8 \\
\hline Sedelighetsforbrytelser & 36,9 & 59,3 & 51,4 \\
\hline Narkotika, legemiddelloven & 38,8 & 2,3 & 1,7 \\
\hline Narkotika, straffeloven & 97,1 & 48,6 & 25,6 \\
\hline Alle forbrytelser & 28,7 & 36,8 & 36,8 \\
\hline
\end{tabular}

Men selv om forklaringer på den økte registrerte kriminaliteten fra 1980 og frem til i dag skyldes endringer i den faktiske kriminalitet og i kriminalpolitikken som i sin tur kan tilbakeføres til samfunnsutviklingen, er dette åpenbart ikke hele forklaringen. For de endringer man har lagt vekt på - fremveksten av det man har betegnet som det senmoderne samfunn - knytter seg til perioden fra slutten av 1970-årene. Økningen i den registrerte kriminalitet begynte imidlertid lenge før dette, da forholdene var ganske annerledes. Fra 1950-årene og inn i 1970-årene var det det statsregulerte vel-ferdssamfunnet - og ikke markedsideologien - som var modellen for samfunns-utviklingen. Innenfor kriminalpolitikken var det troen på behandling - og mistroen til bruk av straff - som var fremherskende. Men i hele den siste 50-årsperioden har den registrerte kriminaliteten vært økende, tilsynelatende upåvirket av de ideologiske og samfunnsmessige endringer. Og selv om økningen synes å ha tiltatt i styrke i den siste 20 -årsperioden, kan dette i hovedsak tilbakeføres til økningen i narkotikaforbrytelser, som var totalt ukjente helt frem til slutten av 1960-årene.

$\AA ̊$ trekke noen konklusjoner på bakgrunn av dette er problematisk. Uten kanskje på ett område. At den registrerte kriminaliteten har steget både under 1950-, 1960- og 1970-årenes "laissez faire"-regime, så vel som under 1980- og 1990årenes "nulltoleranse"-regime, kan kanskje tolkes dit hen at man gjennom kriminalpolitiske tiltak i liten grad kan styre kriminaliteten.

Adresse:

Statens institutt for rusmiddelforskning

$\emptyset$ vre Slottsgate 2B

$\mathrm{Pb} .565$ Sentrum

N - 0157 OSLO 